American Journal of Agricultural and Biological Sciences 2(4): 241-247, 2007

ISSN 1557-4989

(C) 2007 Science Publications

\title{
New Role of Sulfuric Acid In Production of Multicomponent Fertilizers From Renewable Sources
}

\author{
Helena Górecka, Henryk Górecki, Katarzyna Chojnacka, Marzanna Baranska, \\ Izabela Michalak and Agnieszka Zielinska \\ Wroclaw University of Technology, Institute of Inorganic Technology and Mineral Fertilizers, \\ ul. Smoluchowskiego 25, 50-372 Wroclaw, Poland
}

\begin{abstract}
The paper discusses the possibility of using renewable sources: slaughter wastes and wood ashes in the production of NPK fertilizers. The content of macronutrients, micronutrients and toxic elements in these materials was reported. In the present work, poultry feathers were used as fertilizer source of nitrogen, animal bones as the source of phosphorus and wood ash as the source of potassium and micronutrients. Bioavailability of fertilization components was increased by mineralization with sulfuric acid, which transformed keratinous nitrogen of poultry feathers into ammonia nitrogen, hydroxyapatite phosphorus to bioavailable orthophosphate. Also, mineralization of organic content of the materials was achieved. The method of production and the composition of NPKS fertilizer, the content of which was adjusted to the requirements of oil seed rape was provided. The fertilization properties were checked in germination tests.
\end{abstract}

Key words: sulfuric acid, renewable sources, slaughter wastes, pultry feather, animal bones, wood ash, NPK fertilizers

\section{INTRODUCTION}

Each process in the food and agriculture industry has an impact on the environment and there is much concern about environmental pollution. Branches of industry produce wastes of different quality and quantity, which, if not treated, could lead to increasing disposal problems and severe pollution. Agricultural and food industry systems generate by-products, wastes and air emissions with possible impact on the environment $^{[1]}$. Waste resources include wood and wood wastes, agricultural crops and their waste byproducts, municipal solid wastes (MSW), animal wastes, wastes from food processing, aquatic plants and $\operatorname{algae}^{[2]}$. Utilization of various organic wastes in agriculture (e.g. as a fertilizers) depends on several factors, including the characteristics of the waste such as nutrient and heavy metal content, energetic value, odor generated by the waste, availability and transportation costs, benefits to agriculture, and regulatory considerations ${ }^{[3]}$. Application of wood ashes, feather, bones and litter in agriculture (e.g. fertilizers production) is a way to recycle nutrients and to limit consumption of non-renewable resources ${ }^{[1-10]}$.
Large livestock and poultry farms produce considerable quantities of wastes - renewable sources of nutrients. A part of the wastes is directly applied into the soil, producing leachates witch contaminate ground waters. Using the waste as a raw material for biofertilizers would be a sustainable alternative ${ }^{[11]}$. Recently, a number of States in the USA and several countries in Europe are considering the collection, processing, and re-use of waste in order to increase the amount of materials recycled and to reduce the amount of organic matter reaching final disposal sites. The main goal is to make the "waste" a renewable resource that can be utilized and not discarded. In the literature it is reported that organic wastes could be re-used (1) as fertilizers and soil amendments, (2) in the processes of energy recovery (heat, liquid fuels, electricity) ${ }^{[2-4]}$, and (3) in the production of chemicals (volatile organic acids, ammonium products, alcohols $)^{[2]}$.

The conversion technologies for utilizing wastes could be classified into four categories: direct combustion, thermochemical processes, biochemical processes and agrochemical processes ${ }^{[2]}$. The first method - direct combustion is the easiest and the mostly popular. Ashes - the waste product from combustion are proposed to be used as fertilizers ${ }^{[6,7,12-14]}$.

Corresponding Author: Helena Górecka, Wroclaw University of Technology, Institute of Inorganic Technology and Mineral Fertilizers, ul. Smoluchowskiego 25, 50-372 Wroclaw, Poland tel.: +48-713202486 
The present paper discusses using animal wastes as renewable source of fertilizer nutrients: poultry feathers as the source of nitrogen, poultry, cattle and swine bones as the source of phosphorus.

Such a concept provides not only a method of utilization of burdensome wastes, but also enables to reduce consumption of non-renewable resources: high quantities of natural gas used in the production of nitrogen fertilizers, phosphorites - (scarce and nonrenewable source of phosphorus located only in few parts of the world - Arabic countries, U.S., Russia and potash - the source of potassium ${ }^{[15]}$.

The first group - wastes from the poultry industry include a mixture of manure, bedding material or litter (e.g. wood shavings or straw), waste feed, dead birds, broken eggs and feathers removed from poultry houses. Poultry production is one of the fastest growing segments of the agricultural sector in European Union today. Increase that was observed in poultry production in the years 2004-2005, seems to be a permanent tendency. In 2005, poultry production in all EU member states has grown by $1 \%$ to make up $11.1 \mathrm{mln}$ $\mathrm{Mg}$. According to European Commission data, poultry production in Poland in the previous year has grown by $6 \%$ to make up 972 thousand $\mathrm{Mg}$. As a result of the growing poultry industry, poultry slaughterhouses are producing increasing amounts of noxious organic solid by-products and wastes. On the other hand, legislation on the recovery of organic materials for animal feed is becoming more restrictive ${ }^{[16]}$.

Broilers are grown to a weight of about $1.8-1.9 \mathrm{~kg}$ before they are slaughtered. Feather contributes about $10 \%$ to the broiler's live body weight ${ }^{[16]}$. Annually, poultry industry in Poland produces a 97.2 thousand $\mathrm{Mg}$ feather that needs to be utilized in the proper way. Commonly used method of utilization, combustion, chemical or thermal processing are very expensive and cause severe emission problems. Recycling of nutrients from feathers is a subject of interest among animal breeders, because it can be considered a renewable source of nutrients ${ }^{[17,18]}$.

Feathers are composed mainly of C (46\%), N (13.5 $\%), \mathrm{P}(0.5 \%), \mathrm{Mg}(0.12 \%)$ and other microelements $(\mathrm{Zn}, \mathrm{Mn})^{[6]}$. In the literature it is suggested, that although feathers contain high nitrogen concentration, they can not be used directly as fertilizer, because of non-available form of nitrogen ${ }^{[7]}$. Processing of feathers with sulfuric acid causes, that non-available form of nitrogen is converted into available form, thereby liquid fertilizer can be applied directly on fields.

Poultry feather constitutes the most abundant keratinous material in nature ${ }^{[17]}$. Keratin is the main component of feathers, representing nearly $90 \%$ of feather weight. Without appropriate processing, protein nitrogen in feather possesses very low bioavailability to plant, because it is not degraded by most proteolytic enzymes. The proteolytic resistance of keratin results from its structural features such as tight packing of protein chains, hydrogen bonding among polypeptides, and hydrophobic interaction and stabilization of the supercoiled polypeptide chains ${ }^{[19]}$. Nitrogen "hidden" in keratin in feathers is not in available and for this reason it is indispensable to digest feather biomass with e.g. sulfuric acid to mineralize keratin and to transform nitrogen to ammonia form.

The possible method of utilization of feathers is composting - an aerobic degradation of biodegradable organic waste. However, in the case of feather the process is long, it lasts 9-12 months ${ }^{[7]}$. The composted material is odorless and finely textured with low moisture content and can be used as an organic fertilizer ${ }^{[5]}$.

Literature reports that an aerobically digested poultry slaughterhouse waste (mixed fractions of bone meal, blood, offal and autoclaved feather) can be used in agriculture as fertilizers (carrots grew similarly well as those fertilized with a commercial mineral fertilizer) ${ }^{[20]}$.

The second method of utilization of feathers is combustion. Obtained ash provides micro- and macroelements in a concentrated form. Mineral composition of feathers reported in the literature is as follows: Al $119 \mathrm{mg} \cdot \mathrm{kg}^{-1}$, As $0.68 \mathrm{mg} \cdot \mathrm{kg}^{-1}$, Co 0.0009 mg.kg ${ }^{-1}$, Cr 0.78 mg.kg- ${ }^{-1}$ Cu 6.65 mg. $\mathrm{kg}^{-1}$, Fe 227 mg.kg ${ }^{-1}, \mathrm{Mg} 182$ mg.kg ${ }^{-1}$, Mn 10.2 mg.kg ${ }^{-1}$, Zn mg.kg ${ }^{-1}$, $\left.\mathrm{N} 10.4 \%, \mathrm{P}_{2} \mathrm{O}_{5} 0.457 \%, \mathrm{~K}_{2} \mathrm{O} 0.331 \%\right)^{[6]}$.

Other wastes from poultry industry: litter and manure component, have high nutritional value and are used as an organic fertilizer, thus enabling nutrients recycling ( $\mathrm{N}, \mathrm{P}$ and $\mathrm{K}$ ). These components (poultry litter) have traditionally been land spread on soil as an amendment. The composition of both litter and manure is predominantly water and carbon with smaller amounts of $\mathrm{N}$ and $\mathrm{P}$ and trace levels of $\mathrm{Cl}, \mathrm{Ca}, \mathrm{Mg}, \mathrm{Na}$, $\mathrm{Mn}, \mathrm{Fe}, \mathrm{Cu}, \mathrm{Zn}$ and $\mathrm{As}^{[5]}$. Direct combustion of poultry litter produces an ash residue, which retains most of the phosphate and potassium present in the fresh litter. The original nitrogen concentration is variable and lost to the atmosphere during combustion as $\mathrm{NO}_{\mathrm{x}}$. The ash is stable, sterile, easier to handle and transport and more marketable as an organic fertilizer than conventional poultry litter ${ }^{[5]}$.

Disposal of the next waste product - animal bones, is of particular concern. Due to the recent problem with 
bovine spongiform encephalopathy (BSE) crisis in the European beef industry, the use of animal derived products to feed cattle is now restricted. Feeding with meat and bone meal (MBM) to cattle, sheep or goats has been banned within the European Union since July 1994. Also, import and export of MBM to/from/within the European Union has been banned since December 2000. As a consequence, it is necessary to elaborate new methods of utilization of animal by-products. One option of such disposal is the incineration of material such as meat and bone meal residues. Dedicated incineration plants for MBM, as currently used in e.g., Belgium and England, only appear reasonable when sufficient quantities of MBM can be guaranteed in the long term ${ }^{[8]}$. The second disposal option is pyrolysis. Animal wastes could be converted by pyrolysis into fuels, but it is also suggested, that the solid residue could be used for enrichment of agricultural soil with nutrients and minerals ${ }^{[9]}$.

Animal bones are composed in $65-70 \%$ of inorganic substances, mainly hydroxyapatite. The chemical composition of hydroxyapatite is $\mathrm{Ca}_{10}\left(\mathrm{PO}_{4}\right)_{6}(\mathrm{OH})_{2}$. The remaining part of bones is composed of organic matter, mainly fibrous protein collagen ${ }^{[10]}$. Animal bones could be utilized as a source of phosphorus. The content of $\mathrm{P}$ in bones, expressed as $\mathrm{P}_{2} \mathrm{O}_{5}$, is different in bones from various species of animals. The highest concentrations of $\mathrm{P}$ were detected in bovine bones, and the smallest in bones of turkey ${ }^{[6]}$. Animal bones contain not only macroelements $(\mathrm{Ca}, \mathrm{P})$, but also mic roelements (e.g. bones of young chicken contained 4.2 mg. $\mathrm{kg}^{-1} \mathrm{Cu}$, $139.5 \mathrm{mg} \cdot \mathrm{kg}^{-1} \mathrm{Fe}, 4.7 \mathrm{mg} \cdot \mathrm{kg}^{-1} \mathrm{Mn}, 144.0 \mathrm{mg} \cdot \mathrm{kg}^{-1} \mathrm{Zn}^{[11]}$, and hen's bones contained $0.72 \mathrm{mg} \cdot \mathrm{kg}^{-1} \mathrm{~B}, 0.333 \mathrm{mg} \cdot \mathrm{kg}^{-}$ ${ }^{1} \mathrm{Be}, 0.005 \mathrm{mg} \cdot \mathrm{kg}^{-1} \mathrm{Co}, 3.31 \mathrm{mg} \cdot \mathrm{kg}^{-1} \mathrm{Cr}, 62.4 \mathrm{mg} \cdot \mathrm{kg}^{-1}$ Fe, 1048 mg.kg-1 Mg, 1.73 mg.kg-1 Mn, 0.26 mg.kg-1 Mo, 53.5 mg.kg- $\mathrm{Zn}^{[6]}$ ).

Bioavailability and environmental impact to soil resources, the content and availability of toxic elements are necessary to be taken into consideration before any waste material is used in the production of fertilizers ${ }^{[14]}$. Phosphate fertilizers are manufactured from phosphate rocks and, according to their origin, may contain various micronutrients but also fluorine and heavy metals. The content of toxic metals and fluorine in soils as a result of continuous application of phosphate fertilizers is regulated by obligatory law. The mostly important issue is the content of toxic elements introduced per a unit mass of $\mathrm{N}, \mathrm{P}$ or $\mathrm{K}^{[21]}$. If higher levels of toxic metals are introduced in soils, they enter biotic environment: become absorbed by plants and consequently also by its consumers: animals and human $^{[22]}$.
Summarizing, organic wastes could be utilized in agriculture mainly for improving the soil physical and chemical properties and as nutrient sources for growing crops. In most cases, to increase the availability of $\mathrm{N}$ and $\mathrm{P}$, wastes should undergo processing (e.g. composting, digestion with mineral acid-sulfuric acid, combustion).

According to the Directive of Polish Minister of Agriculture and Rural Development the minimum content of nitrogen, potassium and phosphorus in NPK fertilizers is: $2 \%(\mathrm{~m} / \mathrm{m})$ of total nitrogen, $2 \%(\mathrm{~m} / \mathrm{m})$ of potassium in $\mathrm{K}_{2} \mathrm{O}$ form and $2 \%(\mathrm{~m} / \mathrm{m})$ of phosphorus in $\mathrm{P}_{2} \mathrm{O}_{5}$ form ${ }^{[23]}$.

The aim of the present paper was to assess the potential applicability of using renewable sources of fertilizer nutrients in the production of multicomponent NPK fertilizer: poultry feather as the source of nitrogen, animal bones as the source of phosphorus and wood ash as the source of potassium and micronutrients. In the present work, sulfuric acid was used to transform fertilizer nutrients into form which is bioavailable to plants: keratinous nitrogen to ammonia form, phosphorus from hydroxyapatite to soluble orthophosphate. The procedure and technology of preparation of fertilizer for fertilization 1 ha of the arable land for the cultivation of oil seed grain was elaborated.

\section{MATERIALS AND METHODS}

Studied material: Poultry feather, animal bones and wood for the combustion originated from Lower Silesia region in south-west Poland (high capacity of metallurgy industry - copper industry). Sulfuric acid used for mineralization of slaughter wastes was from POCH S.A. Gliwice.

Analytical methods: The basic components of NPK fertilizer: $\mathrm{P}_{2} \mathrm{O}_{5}, \mathrm{~K}_{2} \mathrm{O}$ and micronutrients, and $\mathrm{N}$ were determined by colorimetric analysis, ICP-AES method and Kjeldahl method, respectively. Mercury was analyzed with Mercury analyzer AMA 254 atomic absorption spectrometry. The samples were mineralized with concentrated mineral acids of supra pure grade (from Merck) according to the procedure described previously $^{[6]}$ in a microwave oven (type Milestone MLS-1200 MEGA). The solution after cooling was filtered trough medium paper filter and diluted with demineralized water to the volume $75 \mathrm{ml}$. The solution was analyzed in three repeats by ICP-OES and ICP$\mathrm{MS}\left[{ }^{6]}\right.$ to determine the concentration of metal ions (Al, $\mathrm{As}, \mathrm{B}, \mathrm{Ca}, \mathrm{Cd}, \mathrm{K}, \mathrm{Mg}, \mathrm{Na}, \mathrm{Pb}, \mathrm{Zn})$. For the preparation 
of standard solution $\left(1.0, \quad 10, \quad 100 \quad \mathrm{mg}^{-\mathrm{l}^{-1}}\right)$ the multielemental standard was used (UltraScientific 0.05$\left.1.0 \mathrm{mg} . \mathrm{l}^{-1}\right)$. Mercury was analyzed with Mercury analyzer AMA 254 atomic absorption spectrometry (Czech Republic). Sulphur was determined by ICP$\mathrm{OES}^{[6]}$

Determination of total nitrogen: The total nitrogen content was determined by the Kjeldahl method ${ }^{[24]}$. The method consists of three basic steps: 1) digestion of the sample ( $0.2 \mathrm{~g}$ of solution after digestion of feathers) in $20 \mathrm{ml}$ sulfuric acid $(95 \%)$ with a catalyst $\left(\mathrm{K}_{2} \mathrm{SO}_{4}\right.$ and $\mathrm{CuSO}_{4}$ in the ratio 20:1), which resulted in conversion of nitrogen to ammo nia; 2) distillation - after addition of the base $(\mathrm{NaOH})$, the ammonia was distilled from an alkaline medium and absorbed in boric acid and 3 ) determination of ammonia by titration with a standard solution (0.1 mol.1-1) HCl. For the determination of nitrogen, digestion apparatus (Büchi Digestion Unit K424) and distillation apparatus (Büchi Distillation Unit B-324) were used.

\section{RESULTS AND DISCUSSION}

New standards of organization of wastes disposal and management in developed countries enforce on industry, in particular agricultural food industry with the particular consideration of slaughterhouses and implementation of new technological solutions which will enable wastes utilization with recovery of fertilizer nutrients. This idea enables not only to avoid problems with wastes but simultaneously gives the possibility to save money on import of expensive fertilizer raw materials (natural gas, phosphate raw materials, potassium salts).

In this paper, we propose a special solution of using the properties of sulfuric acid for the digestion of poultry feather and cattle, swine and poultry bones. Taking into account the content of nitrogen in keratin substances (feather), phosphorus (bones) and wood ash (potassium, calcium, magnesium), we have the possibility of composing various complex fertilizers dedicated for special fertilization purposes - potatoes, sugar beets, maize crops and special vegetables according to agricultural recommendations.

The content of micronutrients, micronutrienta and undesirable elements in various renewable resources was analyzed. The average results of measurements of $\mathrm{N}=6$ samples are presented in Table 1, 2 and 3, that show the content of the main fertilizer nutrients, micronutrients and other elements, in particular, four elements $(\mathrm{Pb}, \mathrm{As}, \mathrm{Hg}$ and $\mathrm{Cd})$ the content of which is limited by fertilizer recommendations is presented. The samples originated from the region of Lower Silesia in which non-ferrous metallurgical industry is concentrated.

Table 1: Content of the main macronutrients in renewable fertilizer sources $(\%)(N=6)$

\begin{tabular}{|c|c|c|c|c|c|c|}
\hline & $\mathrm{N}$ & $\mathrm{P}_{2} \mathrm{O}_{5}$ & $\mathrm{~K}_{2} \mathrm{O}$ & $\mathrm{S}$ & $\mathrm{MgO}$ & $\mathrm{CaO}$ \\
\hline Poultry feathers & 15.46 & 0.32 & 0.24 & 2.32 & 0.22 & 0.4 \\
\hline Bones - poultry & 7.15 & 18.72 & 0.16 & 0.153 & 0.85 & 34.1 \\
\hline Swine bone meals & 6.06 & 16.82 & 0.25 & 0.84 & 0.49 & 28.5 \\
\hline Farmyard manure & 0.52 & 0.22 & 0.58 & 0.078 & 0.13 & 0.024 \\
\hline Poultry manure & 1.94 & 1.44 & 0.93 & 0.055 & 0.92 & 0.015 \\
\hline Swine manure & 0.33 & 0.039 & 0.54 & 0.081 & 0.012 & 0.031 \\
\hline Cattle manure & 0.42 & 0.049 & 0.39 & 0.063 & 0.013 & 0.028 \\
\hline Oak ash & 0.01 & 4.9 & 8.94 & 0.32 & 0.59 & 34.8 \\
\hline Birch ash & 0.01 & 3.82 & 7.34 & 0.24 & 5.92 & 33.7 \\
\hline
\end{tabular}

Table 2: Fertilizer micronutrients in renewable sources $\left(\mathrm{mg} \mathrm{kg}^{-1}\right)(N=6)$

\begin{tabular}{llllllllll}
\hline Raw material & $\mathrm{B}$ & $\mathrm{Cu}$ & $\mathrm{Fe}$ & $\mathrm{Mn}$ & $\mathrm{Zn}$ & $\mathrm{Mo}$ & $\mathrm{Co}$ & $\mathrm{Ti}$ & $\mathrm{Na}$ \\
\hline Poultry feathers & 0.14 & 6.65 & 228 & 10.8 & 107 & 0.01 & 0.08 & 3.42 & 1250 \\
Bones poultry & 0.72 & 0.32 & 63.6 & 1.72 & 53.4 & 0.27 & 0.005 & 2.41 & 3550 \\
Farmyard manure & 20.4 & 23.6 & 1280 & 318 & 158 & 1.75 & 1.32 & 6.57 & 882 \\
Poultry manure & 18.75 & 4.24 & 306 & 8.42 & 170.3 & 0.21 & 1.32 & 5.62 & 85.0 \\
Swine manure & 14.9 & 3.6 & 85.3 & 19.6 & 14.9 & 0.92 & 2.62 & 0.04 & 632 \\
Cattle manure & 26.3 & 1.8 & 24.3 & 8.3 & 12.3 & 0.27 & 3.55 & 0.02 & 486 \\
Oak ash & 347 & 169 & 5640 & 1260 & 231 & 3.22 & 7.75 & 0.53 & 830 \\
Birch ash & 597 & 162 & 3860 & 1524 & 1920 & 1.89 & 25.7 & 0.89 & 725 \\
\hline
\end{tabular}


Am. J. Agril. \& Biol. Sci., 2(4): 241-247, 2007

Table 3: Content of elements with content is limiting by fertilizers regulation)* and others elements $\left(\mathrm{mg} \mathrm{kg}^{-1}\right)(N=6)$

\begin{tabular}{llllllllll}
\hline Raw material & $\mathrm{As}$ & $\mathrm{Pb}$ & $\mathrm{Cr}$ & $\mathrm{Hg}$ & $\mathrm{Cr}$ & $\mathrm{Ni}$ & $\mathrm{Be}$ & $\mathrm{Tl}$ & $\mathrm{V}$ \\
\hline Poultry feathers & 0.66 & 3.97 & 0.005 & 0.0204 & 0.002 & 0.002 & 0.002 & - & 105 \\
Bones poultry & 1.12 & 0.273 & 0.824 & 0.0064 & 0.003 & 0.003 & 0.32 & - & 52.6 \\
Swine bone meal & 0.21 & 4.21 & 0.024 & 0.01 & 0.021 & 0.021 & 0.21 & - & 37.4 \\
Farmyard manure & 3.24 & 13.2 & 1.83 & 0.12 & 1.92 & 1.92 & - & - & 1.83 \\
Poultry manure & 18.36 & 7.67 & 0.07 & 0.08 & 0.06 & 0.06 & - & - & 0.82 \\
Swine manure & 13.7 & 3.78 & 0.26 & 0.07 & 1.18 & 1.18 & - & - & 0.75 \\
Cattle manure & 14.7 & 4.23 & 0.021 & 0.03 & 0.72 & 0.72 & - & - & 0.42 \\
Oak ash & 23.6 & 34.62 & 7.32 & 0.0042 & 64.7 & 64.7 & 0.081 & 0.017 & 407 \\
Birch ash & 22.8 & 59.7 & 6.72 & 0.28 & 32.8 & 32.8 & 0.041 & 0.011 & 382 \\
\hline
\end{tabular}

(-) below detection limit of ICP-MS Varian

As an example of preparation of mineralorganic fertilizer produced by the utilization of the renewable sources, the new fertilizer technology solution is presented for obtaining the suspension NPKS fertilizer for nutrition of oil seed rape. This fertilizer can be obtained using poultry feather as the raw material, sulfuric acid, potassium carbonate and non-litter poultry manure. We present a procedure directed to fertilization of 1 ha arable land for the cultivation of oil seed grain.

The new type of fertilizer was composed of the liquid product of mineralization of poultry feathers by sulfuric acid (A) and crude non-litter poultry husbandry manure (B). The component (A) was prepared by mineralization of $1125 \mathrm{~kg}$ of poultry feathers by 2025 $\mathrm{kg}$ of $60 \%$ sulfuric acid in the temperature $85-90{ }^{\circ} \mathrm{C}$ during 4 hours of retention time ${ }^{[25]}$. During the process of acidic digestion, protein-nitrogen from keratin is decomposed into ammonia form of nitrogen which is bioavailable to plants. The post-reaction liquid product was partially neutralized by the addition of $1.863 \mathrm{~kg}$ $\mathrm{K}_{2} \mathrm{CO}_{3}$. According to the agricultural recommendations for oil seed rape nutrition, we added $13.5 \mathrm{~kg}$ of sodium borate $\mathrm{Na}_{2} \mathrm{~B}_{4} \mathrm{O}_{7} * 10 \quad \mathrm{H}_{2} \mathrm{O}$ (borax) and $5.22 \mathrm{~kg}$ of manganese sulfate monohydrate $\mathrm{MnSO}_{4} * \mathrm{H}_{2} \mathrm{O}$ as necessary micronutrients.

The composition of the obtained product, NPKS fertilizer component $(\mathrm{A})$ is presented in Table 4.

Table 4: Composition of fertilizers substrates and semi-products and products -NPK fertilizers

\begin{tabular}{|c|c|c|c|c|c|}
\hline Composition & Poultry feathers & Product NPS (A) & $\begin{array}{l}\text { Non-litter poultry } \\
\text { manure (B) }\end{array}$ & $\begin{array}{c}\text { Suspension } \\
\text { fertilizers (NPKS) }\end{array}$ & Birch ash \\
\hline \multicolumn{6}{|l|}{$\begin{array}{l}\text { Macronutrients } \\
(\%)\end{array}$} \\
\hline $\mathrm{N}$ & 16.8 & 6.02 & 1.17 & 3.01 & - \\
\hline $\mathrm{P}_{2} \mathrm{O}_{5}$ & 0.36 & 0.13 & 1.79 & 1.26 & 3.82 \\
\hline $\mathrm{K}_{2} \mathrm{O}$ & 0.32 & 4.01 & 0.91 & 1.80 & 7.25 \\
\hline $\mathrm{S}^{2}$ & 2.12 & 12.71 & 0.08 & 3.69 & 0.21 \\
\hline $\mathrm{MgO}$ & 0.18 & 0.06 & 0.012 & 0.023 & 5.92 \\
\hline $\mathrm{CaO}$ & 0.42 & 0.15 & 0.32 & 0.271 & 33.72 \\
\hline \multicolumn{6}{|l|}{$\begin{array}{l}\text { Micronutrients } \\
\left(\mathrm{mg} \cdot \mathrm{kg}^{-1}\right)\end{array}$} \\
\hline B & 6.15 & 202 & 24.2 & 151 & 28.2 \\
\hline $\mathrm{Mn}$ & 102 & 219 & 8.34 & 162 & 13280 \\
\hline $\mathrm{Zn}$ & 205 & 68.6 & 13.8 & 29.45 & 1880 \\
\hline $\mathrm{Fe}$ & 208 & 70.1 & 28.6 & 40 & 3950 \\
\hline Mo & 0.01 & 0.1 & 0.24 & 0.21 & 2.7 \\
\hline $\mathrm{Co}$ & 0.08 & 0.025 & 1.24 & 2.29 & 4.6 \\
\hline $\mathrm{Cu}$ & 7.3 & 2.5 & 2.21 & & 142 \\
\hline $\begin{array}{ll}\text { Toxic } & \text { metals } \\
\left(\mathrm{mg}^{\prime} \mathrm{kg}^{-1}\right) & \end{array}$ & & & & & \\
\hline $\mathrm{Mh}$ & 0.005 & 0.002 & 0.03 & 0.022 & 0.01 \\
\hline As & 1.03 & 0.34 & 16.2 & 11.95 & 8.80 \\
\hline $\mathrm{Pb}$ & 0.29 & 0.11 & 4.16 & 3.02 & 18.7 \\
\hline $\mathrm{Cd}$ & 0.12 & 0.04 & 0.017 & 0.023 & 0.22 \\
\hline
\end{tabular}


The final product - suspension fertilizer NPKS was composed of three components:
? NPKS - 6-0.13-4.0
(A)
$1.8 \mathrm{Mg}$
? non-litter poultry manure
(B) -
$4.5 \mathrm{Mg}$

$\begin{array}{lr}\text { ? gelling agent (bentonite-attapulgite) } & 0.126 \mathrm{Mg} \text {. } \\ \text { The final product }- \text { mineral-organic fertilizer NPKS }\end{array}$ (3:1.3:1.8:3.4) in the dose $6.3 \mathrm{Mg}\left(5.9 \mathrm{~m}^{3}\right)$ per ha contains all nutrients and micronutrients necessary to obtain good grain yield, seed grain per ha with the aimed composition grains. We propose preliminary application of ash to improve soil, with the application of $1 \mathrm{Mg}$ of wood ash as deacidifying agent ${ }^{[26]}$ and the additional source of potassium.

According to agricultural experience ${ }^{[27]}$, nutrients removal varies according to the fertilizer supply level and average value for $3.5 \mathrm{Mg}$ grains with the corresponding quantities of straw was as follows: 186 $\mathrm{kg} \mathrm{N}, 80 \mathrm{~kg} \mathrm{P}_{2} \mathrm{O}_{5}, 180 \mathrm{~kg} \mathrm{~K}_{2} \mathrm{O}, 220 \mathrm{~kg} \mathrm{CaO}, 32 \mathrm{~kg}$ $\mathrm{MgO}$ and more than $65 \mathrm{~kg} \mathrm{~S}^{[28]}$.

Rape, being a crucifer, requires for fertilization high levels of sculpture - approximately twice as much as phosphorus. The proposed suppliers of NPKS will be optimal for rape yield 3.0-4.0 Mg.ha ${ }^{-1}$ with the proper content of edible oil in the rape grains. The important property of this product is the composition of organic and mineral components in the fertilizer suspension. The presence of organic matter in the suspension is well utilized by oil rape because of its long period of vegetation. Introduction of the acidic form of NPK fertilizer reduces ten times the emission from collecting husbandry waste ammonia and sulfur compounds.

Table 5: Chemical and physical prosperities of the organicmineral fertilizers

\begin{tabular}{|c|c|c|}
\hline Component & Unit & Composition \\
\hline $\mathrm{N}$ & $\%$ & 3,01 \\
\hline $\mathrm{P}_{2} \mathrm{O}_{5}$ & $\%$ & 1.26 \\
\hline $\mathrm{K}_{2} \mathrm{O}$ & $\%$ & 1.80 \\
\hline B & $\%$ & 0.015 \\
\hline $\mathrm{Mn}$ & $\%$ & 0.015 \\
\hline $\mathrm{S}$ & $\%$ & 3.38 \\
\hline agent-bentonite & & \\
\hline Component/* gaseous phase & & \\
\hline S compound & $\mathrm{S} \mathrm{mg} \cdot \mathrm{m}^{-3}$ & 0.87 \\
\hline $\mathrm{N}$ compound & $\mathrm{N} \mathrm{mg} \cdot \mathrm{m}^{-3}$ & 0.21 \\
\hline $\mathrm{pH}$ & & 6.1 \\
\hline viscosity & $\mathrm{cP}$ & $40-50$ \\
\hline \multicolumn{3}{|c|}{$\begin{array}{l}\text { * Modification of the chemical composition of the non-litter poultry } \\
\text { husbandry manure caused evident decreasing of ammonia and S- } \\
\text { compounds emission. We determined under surface of the collected } \\
\text { poultry manure: } \\
13.2 \mathrm{mg} \mathrm{S} \text { - compound } / \mathrm{m}^{3} \text { ambient air } \\
6.5 \mathrm{mg} \mathrm{N}-\text { compound } / \mathrm{m}^{3} \text { ambient air }\end{array}$} \\
\hline
\end{tabular}

The properties of prepared fertilizer containing high concentration of sulfate ions and $\mathrm{pH}$ below 6.2 were determined as germination capacity tests using barley as test plants. Applying normal dose of suspension fertilizer, the germination capacity was higher than during the application of raw poultry manure $-45 \%$.

\section{CONCLUSIONS}

Presented technological solution of utilization of renewable source of fertilizer nutrients enable to protect environment from undesirable emissions of ammonia and sulphur volatile organic compounds. Such a solution should enable to reduce many times (8-10) emission of odor gases ${ }^{[29]}$.

This concept and new technological solution is the aim of development project with the co-operation with large poultry slaughterhouse with daily production 7-10 $\mathrm{Mg}$ of waste poultry feather. The obtained fertilizer will be used in local farms. The process is going to be implemented on technical scale.

\section{ACKNOWLEDGMENTS}

This research was financially supported by Polish Ministry of Science and Higher Education (grants No. T09B 14829).

\section{REFERENCES}

1. Kroyer, G. Th., 1995. Impact of Food Processing on the Environment an Overview. Lebensm.-Wis. u. Technol. 28: 547-552.

2. Demirbas, A., 2001. Biomass resource facilities and biomass conversion processing for fuel and chemicals. Energy Conv. Manag. 42: 1357-1378.

3. Westerman, P.W. and J.R. Bicudo, 2005. Management considerations for organic waste use in agriculture. Bioresource Technol. 96: 215-221.

4. Huber, G.W., S. Iborra and A. Corma, 2006. Synthesis of Transportation Fuels from Biomass: Chemistry, Catalysts, and Engineering. Chem. Rev.106: 4044-4098.

5. Kelleher, B.P., J.J Leahy, A.M. Henihan, T.F. O'Dwyer, D. Sutton and M.J. Leahy, 2002. Advances in poultry litter disposal technology - a review. Bioresource Technol. 83: 27-36. 
6. Chojnacka, K., M. Baranska, H. Górecka and H. Górecki, 2006. Utilization of animal bones, feather and wood ash in the making of mineral fertilizers. Przem. Chem. 85/8-9: 1256-1259

7. Górecki, H., H. Górecka and K. Chojnacka, 2006. The technological applicability of renewable phosphorus sources. Przem. Chem. 85/8-9: 814-818.

8. Conesa, J. A., A. Fullana and R. Font, 2005. Dioxin production during the thermal treatment of meat and bone meal residues. Chemosphere 59: 85-90.

9. Chaala, A. and C. Roy, 2003. Recycling of Meat and Bone Meal Animal Feed by Vacuum Pyrolysis. Environ. Sci. Technol. 37: 4517-4522.

10. Samuel, L., M.D. Turek and J.B. Lippincott, 1985. Orthopaedics: Principles and Applications, second ed.,113-136.

11. Arkhipchenko, I.A., M.S. Salkinoja-Salonen, J.N. Karyakina and I. Tsitko 2005. Study of three fertilizers produced from farm waste Appl. Soil. Ecol., 30: 126-132.

12. Górecka, H., Z. Dobrzanski, H. Górecki and K. Chojnacka, 2004. Fireplace ashes as deacidification agent and fertilizer. New agrochemicals and their safe use for health and environment, in: Chemistry for Agriculture (Edited by H. Górecki, Z. Dobrzanski, P. Kafarski), 5: 1-8.

13. Górecka, H., K. Chojnacka, H. Górecki and Z. Dobrzanski, 2004. Wood fireplace ashes as the raw material for the fertilizers used in the fertilization of the homestead garden. Pol. J. Chem. Tech. 4:15-19.

14. Górecka, H., K. Chojnacka and H. Górecki, 2006. The application of ICP-MS and ICP-OES in determination of micronutrients in wood ashes used as soil conditioners. Talanta, 70: 950-956.

15. Gorlach, E. and T. Mazur, 2001. Chemia rolna. PWN.

16. Salminen, E. and J. Rintala, 2002. Anaerobic digestion of organic solid poultry slaughterhouse waste - a review. Bioresource Technol., 83:13-26.

17. Bertsch, A. and N. Coello, 2005. A biotechnological process for treatment and recycling poultry feathers as a feed ingredient. Bioresource Technol., 96: 1703-1708.
18. Park, B.B., R.D. Yanai, J.M. Sahm, D.K. Lee and L.P. Abrahamson, 2005. Wood ash effect on plant and soil in a willow bioenergy plantation. Biomass Bioenerg., 28: 355-565.

19. Guillermo, Coward-Kelly, V.S. Chang, F.K. Agbogbo and M.T. Holtzapple, 2006. Lime treatment of keratinous materials for the generation of highly digestible animal feed: 1. Chicken feathers. Bioresource Technol., 97: 1337-1343.

20. Salminen, E., J. Rintala, J. Härkönen, M. Kuitunen, H. Höogmander and A. Oikari, 2001. Anaerobically digested poultry slaughterhouse wastes as fertiliser in agriculture. Bioresource Technol., 78: 81-88.

21. Chojnacka, K., M. Baranska, H. Górecka and H. Górecki, 2006. Utilization of animal bones, feather and wood ash in the making of mineral fertilizers. Przem. Chem., 85/8-9: 1256-1259.

22. McLaughlin, M.J., D.R. Parker, and J.M. Clarke, 1999. Metals and micronutrients - food safety issues Field. Crop. Res., 60: 143-163.

23. Directive of Polish Minister of Agriculture and Rural Development, 2004.Journal of Laws, Tom No 04.236.2369.

24. Brenner JM. 1965. Total Nitrogen. In: Black CA, Evans DD, Ensminger LE, White JL, Clark FE, editors. Methods of soil analysis (chemical and microbiological properties). New York: Academic Press, 1149-1178.

25. Patent Appl. PL 374562 (2005), BUP 30-10-2006 22/2006

26. Górecka H., Chojnacka K., Dobrzanski Z., Górecki H., 2005. Bioavailability of macronutrients, micronutrients and toxic elements from wood ashes used as fertilizer and soil deacidifying agent POL J ENVIRON STUD 14(suppl. 3): 14-18

27. Norma PN $-88 / \mathrm{C}-87015$

28. Czuba R., 1996. Mineral fertilization of cultivated plants, Police

29. Patent Appl. PL 360443 (2003. BUP 31-12-2004 25/2004) 